\title{
Problems and Obstacles the Lecturers of English Language Encounter in Universities
}

\section{Ervin Balla PhD Candidate}

University of Tirana, Albania

Email: Ervin_balla@yahoo.com

\section{Doi:10.5901/jesr.2014.v4n4p344}

\begin{abstract}
In this scientific article I have tried to treat some usual problems that the lecturers of English language encounter in their daily work in the Universities. The problems that they encounter are diverse and the way how they treat them is diverse too. Teaching English is not an easy process, it takes time and efforts in order to achieve our aim. It is a process that has to be treated step by step, and to try to give a different prospective to my point of views
\end{abstract}

Keywords: Teaching, communication teacher students, teaching learning strategy

\section{Teaching Process}

The process of teaching is not always an easy procedure and without problems. The commitment and challenges of the teachers of English language if they want to reach good results in their job is very high. According to (Johns T.F 1981), after the analysis of a poll from 100 teachers from all over the world, these results were achieved according to their importance.

These were the results:

1. The timetable is paid a small attention, not a priority

2. The lack of communication with the respective designated teacher

3. Lower status then the teacher of the subject

4. Isolation and the lack of communication with other teachers of English

5. Lack of respect from students

In another case the discussion is related to the way teacher should speak (Poulson L 1998). In other words do the teachers use a simplified and comprehensive language during the class?

(Chaudron 1998) in a collection of his research regarding the speech of teacher in class shows some things which he noted:

- Way of speaking is very slow

- Pauses are longer and more frequent

- The affirmative sentences are used instead the interrogative ones

- Very frequently teachers repeat themselves, so saying the same things

- The way of pronunciation is very frequently overrated

- The vocabulary that they use is poor and involves only the basic one

(Nunan 1991), introduces a better strategy for the teachers that has to do with the fact that teachers better enrich the vocabulary by using periphrases and repetition and rhetoric, rather simplify the grammar and vocabulary. He introduces a survey regarding the time that teacher should wait to get an answer from the students at the moment he asks a question to the class. From this survey was noted that in those classes where the teacher gave a longer time to the students to answer, the participation of the students was higher. Some other effects noted were:

- The number of the answers of the students increased

- The students gave a bigger contribution regarding the verbal communication during the class

- An increase of the comparison of the data of the students

- An increase of speculative answers of the students

If the students read the biography of Marie Curie or Thomas Edison's biography they may be motivated to continue their studies for medicine or engineering. At the moment when the student starts studies in respective branches of study, only the will is not enough. Learning the technical terms requires a lot of time and the teacher does not have the necessary time to teach all the terms that the student might need. The best thing that the teacher can do is to encourage the students to use the vocabulary. According to John J. Higgins there are three obstacles that the lecturers of English language face at the universities: 
1. Presence of the students that have problems with learning the English language and give no result of improvement

2. Multitude of standards. Very frequently the number of students in classrooms is higher and the teachers are faced with a multitude of abilities and levels

3. The third problem has to do with unavailability of time. At the end of course it seems like the knowledge of students are not increased, and taking into consideration the fact that we cannot ask for extra time, we should use the time we have as effectively as possible (Swales J. 1988)

Teachers can face successfully all the difficulties that they encounter during the learning process, of course with the proper qualifications. This means that the teachers should have knowledge for the field that they are teaching students, with specific terms. For i.e. the teachers that teach legal English should have knowledge in the judicial field or the teachers that teach medicine English should have knowledge in the vocabulary of this field. But how can this be achieved? Is it possible? Of course it is.

A successful teaching of English for specific purposes can be achieved through the training of the teachers in the respective fields. In these trainings teacher have the chance to get acknowledged with the contemporary texts in different fields, they also have the opportunity to meet other ESP participating teachers. They will treat and discuss different problems that they encounter during their teaching process

One of the most common problems that the teacher of the English language encounter during his daily routine work is the teaching of the students with different levels of English language. Some of them come supplied with a very high level of English language (one of the factors is the opening of Albania and the free movement of people), another factor remains the fact that Albanians are really fond of the foreign languages paying really a great attention to them, (here we can refer to the number of students that go to study abroad) and on the other hand we have students the level of language of whom is very superficial or low (where in the best case they know only the basic words. So in this case we encounter a class mixed with students of different level of knowledge in the foreign language (in this case the English language). All the English teachers encounter this type of problem, unless any tough selection is done previously according to their ability to speak English. What can be done in these circumstances?

\section{What Should be Done in the Class in these Circumstances?}

In such cases the best thing to do according to my experience is the division of the class in groups according to the level of knowledge of language. While a group is advanced could be studying a part of grammar, that belongs to the advanced level, as it could be the "past continuous", the other group that belongs to a less advanced group could be studying a part in reading including the extraction of the new words, paraphrasing simple words, or easy parts of grammar such as simple present, or the time of description of events in the parts that they were reading etc. So the less advanced group can pass into other assignments appropriate for their level, while the other advanced group can work on other independent works such as listening of recorded part in tape etc. Within the class can be worked independently with the students adjusting to their level in a way so the others could not lose their interests to the things being discussed because these are either to simple or to complicated so they cannot understand.

In the schools that there are self study centres, the teacher can send a student to study there in a way that he can have more time to spend with the other group which asks for more of his attention. In the majority of these self study centres should be enough space for the students to deal with their favourite activities in English language. For i.e. whilst a group of three or four persons could be focused in the grammar analysis, another group could be focused in the listening a tape, another group could be focused in some facts cited in the English, maybe another group could be focused in the screen of a computer.

One of the things that can help the students is when the teachers use the same material with the class; they sometime can encourage the students to do different assignments according to their abilities (Harkin J. 2001). A reading text can have questions for three different levels. The teacher tells to the students to see how fast they can sort them out. The best student ends quickly both first levels and works hard to sort out the third and the most difficult

In an exercise for the study of the language, the teacher could ask for a review by some students, but he can ask others to use a new language with more complex sentences. Finally in the division in roles and other activities in group the teacher can secure students to have roles or functions that are appropriate for their levels.

It is understandable to believe that within a heterogeneous group, the students will find their level (Corder 2002). In activities, in spoken and written the best students will be bolder. They will understand better and faster, but the risk of that is that these students will get bored by the slowness of their friends, or they will be frustrated by their incapability of them to continue at the same pace with their friends. 
Some teachers use strategies for students to help each other, so the best students help the weak ones. They work in groups of two or bigger ones, however this should be done with a great sensitiveness, in a way that the weak students should not feel underestimated by their peers who know more or oppressed by their obligatory role in teaching

Many teachers faced with students of different levels, adopt a mixture of selections as those we mentioned above.

Another delicate problem that very frequently occurs to the teachers of English language is: small schools and a growing demand of students to learn English language, this makes us face small classrooms with a great number of students. In big classrooms it is difficult for the teacher to have an eye contact with the students at the end of the class, and it is difficult for the students to ask and receive individual attention. In the majority of the cases it is impossible to have students that can change their roles in the group of work, and very frequently the big classes are difficult especially for new and inexperienced teachers

One of the best solutions that a teacher can do is the distribution of work sheets to the students. This helps students and the teachers in their work to achieve satisfactory results in meeting their targets.

Use of the groups of works, especially in the classes with many students plays an fundamental role because this method maximises the participation of the students (Littelwood W. 1981). Even if the formation of these groups can be difficult, there are always easy ways to do that.

\section{Use of Work in Groups}

When we use the work in groups, in small groups or big ones, it is important to give guidelines for the way how the activity or the assignment that is given to the students. Some teachers use the help of the leaders of the groups. They can be used to deliver photocopies, check if the students in their group have understood the assignment, collect the homework etc. The classes with many students often occurs in big classrooms. Very frequently the teachers should assure that whatever they say could be heard or seen by whole the class. Of course that the classrooms with many students have their disadvantages, but they also have their advantages, for i.e. the humour is nicer, the feeling of a good class is warmer. The experienced teachers use this advantage to organise and involve many from these groups. The fact is that none chooses or wants to work in classes with many students, because this makes the work even more difficult than what it is, however it is a true fact that we teachers find ourselves in classes with 50 or 60 students, or sometimes their number reaches 100.

One of the biggest problems that the teachers of English encounter into the Albanian universities, is that the students use their mother tongue rather than the English language to perform their assignments during their classes. This can be because they want to communicate something important. Another factor is that most of them think that if they use their mother tongue they will make fewer mistakes and their peers will not mock them (as the majority of the claims during the English course).

From 250 grown up students that were asked, 120 answered that they do not use the English language because they do not want to make mistakes. 110 others said that they will start to express themselves in English when they feel more secure about their vocabulary, and 20 others gave other factors that why they do not express themselves in English, such as, emotions, fear of not to confuse their words with another language that they know such as Italian or French or Russian language (sometimes the part time students in university are above 40)

However the majority of teachers agree to this, the students should practice the English language instead of mother tongue or any other language that they speak. This is the most important thing that they should do during the English class. There are many things that should be done to reach this: first teacher should encourage the students to speak in English regardless their mistakes that they can make when they speak, this would help to overcome their fears and practise the English in class. One of the things that the teachers should do is to tell the students that there is not a total obstacle of the mother tongue, so in other words there can be a little use of the mother tongue when they read the text in English, but when they solve exercises it may lose its purpose if it is not done in English (Corder N. 2007). The teachers should make it clear to the students that they would like to listen only in English. Very frequently they can ignore if their students speak in their mother tongue. Teacher themselves should speak in English most of the time, so with the correct use to the tapes videos and conversation in English students are exposed all the time to the sounds of English language. Very frequently teachers have to move all over their classroom to encourage the students speak English. This technique can change the behaviour of students to English language within a short period of time.

But what happens if the students are not cooperating? All the experienced teachers remember the time when the students in purpose were not very cooperating. The lack of cooperation can have different shapes such as: the continuous noise in the class, not being very attentive to the teacher, not making the home works, refusal to do exercises in class, arriving late at the class, bad behaviour etc, sometime things can go really bad and students can complaint to 
the authorities There are many things that can be done to avoid these problems for example teachers can talk to students outside the classroom. They can ask students what they feel for the class, why there problems and what can be done to sort the problems. The teacher should try to tell to the class that the activity that the class likes so much will do only if the class takes its normal function or they will continue with more formal ways of teaching the language (Richards J.C. 2001). The teacher should not face all the unpleasant situation on his own. They should talk and discuss with their colleagues for the problems of teaching and learning. They could ask one of their colleagues to come to his class and to assist him. Teacher can talk to his students for the problem of teaching and learning. They can discuss to the student and see what is the expectation the students from learning the English and from the teacher himself. This would work as a contract for the improvement of the language, and the subjects that are covered can involve such feelings as: students should not use their mother tongue, what should students by home works, arrival in time, being more cooperating during the class etc, but also the teacher should behave as a good teacher. When this contract is closed will create a point of reference for both parties in the future

\section{Conclusions}

As we saw teachers encounter many problems during their daily work. Those problems are of various types. Some have to do with circumstances of teaching process such as the big classes, classes with a great number of students, poor conditions of classes etc, some others have to do with the relation student teacher, good relations means good acquisition of English language. The division of class into smaller groups can result in achieving high standards of learning English. How good can be the communication in English language for the improvement of level of English in students. Their urge from the teachers to communicate freely in English regardless their mistakes. These and other things I have tries to cover in my article.

\section{References}

Corder N., 'Learning to teach adults' 2002 Routledge Falmer

Richards J. 'Approaches and methods in language teaching' 2001 Cambridge University press

Heargraves A. (1992) "Teacher development and educational change" Routledge USA

Hutchinson T., (1987) "English for specific purpose" Kembridge University Press.

Corder N., (2008) "Learning to teach adults" Routledge

Harmer J., (2010) "How to teach English" Pearson Longman

Hutchinson T., \& Waters A, (1987), "English for specific purposes", Cambridge University Press

Tamo A, Rapti E, Karaj Th, (2005), "Mësimdhënia dhe të nxënit", Tiranë , Mokra,

Aliu I., (2004) "Metodologji e mësimnxënies", Tirane Pegi

Lynch T., (1996)" Communication in the language classroom", Oxford

Thomas S. Farrell C and George M. Jacobs (2010) "Essentials for Successful English Language Teaching" Continuum

Diller, K. C., (1971). "Generative Grammar, Structural Linguistics, and Language Teaching.: Newbury House Publishers

Coleman, A., (2012) "The Teaching of Modern Foreign Languages in the United States". Literary Licensing, LLC

Howatt, A. P. R., ( 198 4) "A History of English Language Teaching". Oxford University Press

Gauntlett J. O., (1957) "Teaching English as a Foreign Language". London: Macmillan

Palmer, H. E., (1968), "The Scientific Study and Teaching of Languages". London: Oxford University Press,

Thorne. K., (2003) "Blended Learning: How to Integrate Online and Traditional Learning" Great Britain Clays

Macdonald J., (2008) "Blended learning and online tutoring" England, Gower publishing

Palmer, H. E. (1934) "Specimens of English Construction Patterns". Department of Education

Billows, F. L. , (1961). "The Techniques of Language Teaching. London": Longman

Jakobovits, L. A., ( 1970). "Foreign Language Learning: A Psycho linguistic Analysis of the Issues". Newbury House

Bentley T., (1998) "Learning beyond the classroom " Routledge

Richard J and Rodgers Th., (2001) "Approaches and methods in language teaching" Cambridge University Press

Burton G., (1980) "Teaching English as 